\title{
Peningkatan Kemampuan Anak dalam Mengenal Konsep Bilangan Melalui Penggunaan Media Pembelajaran Berbasis Alam
}

\author{
Abdul Syukur \\ Yulianty Thabita Fallo \\ Program Studi Pendidikan Luar Sekolah Fakultas Keguruan dan Ilmu Pendidikan \\ Universitas Nusa Cendana \\ Email : abdulsyukur376@gmail.com
}

Received February 2019, Accepted March 2019, Published April 2019

\begin{abstract}
Enhancing Early Childhood Ability to Know the Concept of Numbers through Using of Learning Media Based on Nature. The purpose of this study is to improve the ability of children to understand the concept of numbers through using of learning media based on nature. The type of research conducted is Classroom Action Research with data collection techniques in the form of observations and performance and then analyzed using qualitative descriptive analysis techniques. This research was conducted in two cycles, namely cycle I and cycle II. In the first cycle the percentage of student performance achieved $30 \%$ of the percentage before use the cycle, in this cycle students who managed to achieve the Minimum Completeness Criteria drove 11 people who had not succeeded in achieving a large of minimum completeness criteria students could participate in learning activities well and encourage very active when using media. So the research continued the second cycle in cycle II, the percentage reached $45 \%$ and all students who succeeded in reaching 20 people managed to reach the minimum completeness criteria while the observations showed that students were very interested in learning to use the prepared media. From the results of the implementation of the first cycle and the second cycle the increase in the percentage of student learning completeness reached $75 \%$ of the percentage before cycle use. Thus, it can be denied that the learning media based on nature can improve the ability of children to understand the concept of numbers to support learning activities in early childhood can use media that are either natural media or media that have been supportive in order to produce learning that is conducive to children's abilities.
\end{abstract}

Keywords: Improvement, Number Concept, Learning Media Based on Nature

\begin{abstract}
Abstrak: Peningkatan Kemampuan Anak Usia Dini dalam Mengenal Konsep Bilangan Melalui Penggunaan Media Pembelajaran Berbasis Alam. Tujuan dari penelitian ini adalah untuk meningkatkan kemampuan anak dalam mengenal konsep bilangan melalui penggunaan media pembelajaran berbasis alam. Jenis penetian yang dilakukan adalah Penelitian Tindakan Kelas (PTK) dengan teknik pengumpulan data berupa observasi dan unjuk kerja kemudian dianalisis menggunakan teknik analisis deskriptif kualitatif. Penelitian ini dilakukan dalam dua siklus yaitu siklus I dan siklus II. Pada siklus I persentase keberhasilan unjuk kerja siswa mencapai $30 \%$ dari persentase sebelum penggunaan siklus, dalam siklus ini siswa yang berhasil mencapai kriteria ketuntasan minimum (KKM) berjumlah 11 orang sedangkan yang belum berhasil mencapai KKM berjumlah 9 orang sedangkan hasil observasi yang dilakukan oleh observer sebagian besar siswa dapat mengikuti kegiatan pembelajaran dengan baik dan bersikap sangat aktif pada saat penggunaan media. Sehinngga penelitian ini berlanjut ke siklus II pada siklus II persentase keberhasilan mencapai 45\% dan seluruh siswa yang berjumlah 20 orang berhasil mencapai KKM sedangkan hasil observasi menunjukan bahwa siswa pun merasa sangat tertarik belajar menggunakan media yang dipersiapkan. Dari hasil pelaksanaan siklus I dan siklus II maka perbandingan kenaikan persentase ketuntasan belajar siswa mencapai $75 \%$ dari persentase sebelum penggunaan siklus. Dengan demikian maka dapat disimpulkan bahwa penggunaan media pembelajaran berbasis alam dapat meningkatkan kemampuan anak dalam mengenal konsep bilangan untuk itu disarankan agar setiap kegiatan pembelajaran pada anak usia dini selalu menggunakan media baik itu media alam maupun media yang telah dimodifikasi agar dapat menciptakan suasana belajar yang kondusif sehingga kemampuan anak pun dapat ditingkatkan.
\end{abstract}

Kata Kunci : Peningkatan, Konsep Bilangan, Media Pembelajaran Berbasis Alam.

\section{PENDAHULUAN}

Pendidikan Anak Usia Dini (PAUD) umumnya adalah pendidikan yang memberikan pengasuhan, perawatan, dan pelayanan kepada anak Usial 0 sampai 6 tahun dengan memberian rangsangan pendidikan untuk membantu pertumbuhan dan perkembangan jasmani dan rohani agar anak memiliki kesiapan dalam memasuki sekolah dasar dan kehidupan tahap berikutnya. Pendidikan usia dini merupakan 
wahana pendidikan yang sangat fundamental dalam memberikan kerangka dasar terbentuk dan berkembangnya dasar-dasar pengetahuan, sikap dan keterampilan pada anak (Nazariah, 2016; Tursiyah, R., \& Halida, 2014). Berdasarkan penjelasan dalam Undang-Undang Sistem Pendidikan Nasional nomor 20 tahun 2003pasal 1 ayat 14 yang menyatakan pendidikan anak usia dini adalah suatu upaya pembinaan yang ditujukan kepada anak sejak lahir sampai dengan usia enam tahun yang dilakukan melalui pemberian rangsangan pendidikan untuk membantu pertumbuhan dan perkembangan jasmani dan rohani agar anak memiliki kesiapan dalam memasuki pendidikan lebih lanjut (Ambarsari, Syukri, \& Miranda, 2014).

Usia 4-6 tahun, merupakan masa peka bagi anak. Anak mulai sensitif untuk menerima berbagai upaya perkembangan seluruh potensi anak. Masa peka adalah masa terjadinya pematangan fungsi-fungsi fisik dan psikis yang siap merespon stimulasi yang diberikan oleh lingkungan. Masa ini merupakan masa untuk meletakkan dasar pertama dalam mengembangkan kemampuan fisik, kognitif, bahasa, sosial emosional, konsep diri, disiplin, kemandirian, seni, moral, dan nilai-nilai agama. Oleh sebab itu dibutuhkan kondisi dan stimulasi yang sesuai dengan kebutuhan anak agar pertumbuhan dan perkembangan anak tercapai secara optimal.

Pembelajaran untuk anak usia dini memegang peranan yang sangat penting bagi pembentukan kemampuan dan sikap belajar pada tahap yang lebih lanjut. Dalam suatu pembelajaran peran guru bukan semata-mata memberikan informasi, melainkan juga mengarahkan dan memberi fasilitas belajar (directing and facilitating the learning) agar proses belajar lebih memadai. Sebagaimana yang dikemukakan oleh Ali (Zein, 2016)bahwa pembelajaran adalah upaya yang dilakukan guru dalam merekayasa lingkungan agar terjadi belajar pada individu siswa.

Proses pembelajaran akan berlangsung dengan baik jika pendidik mempunyai dua kompetensi utama yaitu kompetensi substansi materi pembelajaran dan kompetensi metodologi pembelajaran. Untuk pendidik harus kreatif melihat potensi lingkungan dan mendesain kegiatan pembelajaran yang menyenangkan anak.
Lingkungan alam merupakan salah satu komponen terpenting dalam pengembangan tujuan, isi dan proses pendidikan pada anak usia dini. Esensi tujuan pendidikan pada anak usia dini diantaranya adalah membantu anak memahami dan menyesuaikan diri secara kreatif dengan lingkungannya. Lingkungan yang dimaksud memiliki konotasi pemahaman yang luas mencakup segala sumber yang ada dalam lingkungan anak (termasuk dirinya sendiri), lingkungan keluarga dan rumah, tetangga (tetangga pedagang, tetangga dokter, tetangga peternak, dan petani), lingkungan yang berwujud makanan, minuman serta pakaian, gedung atau bangunan, kebun, persawahan dan lain-lain.

Ide dasarnya adalah pendidikan pada anak dilakukan dengan mengajak anak dalam suasana sesungguhnya melalui belajar pada lingkungan alam sekitar yang nyata. Bentuk pengajaran ini dilakukan sebagai upaya menentang bentuk pengajaran yang cenderung intelektualisme dan verbalistik. Menurut Ligthart menyatakan sumber utama bentuk pengajaran ini adalah lingkungan di sekitar anak, dimana melalui bentuk pengajaran ini akan tumbuh keaktifan anak dalam mengamati, menyelediki serta mempelajari lingkungan (Lasaiba, 2016).

Kondisi lingkungan yang sesungguhnya juga akan menarik perhatian spontan anak sehingga anak memiliki pemahaman dan kekayaan pengetahuan yang bersumber dari lingkungannya sendiri. Bahan-bahan pengajaran yang ada pada lingkungan sekitar anak akan mudah diingat, dilihat dan dipraktikan sehingga kegiatan pengajaran menjadi berfungsi secara praktis. Inti pengajaran barang sesungguhnya adalah mengajak anak pada kondisi lingkungan sesungguhnya. Semua bahan yang ada di lingkungan sekitar anak dapat dipakai sebagai pusat minat atau pusat perhatian anak. Bahan pengajaran dari lingkungan oleh Ligthart dikelompokan dalam tiga kategori, yaitu lingkungan alam (sebagai bahan mentah), lingkungan produsen atau lingkungan pengrajin (pengolah dan penghasil bahan mentah menjadi bahan jadi) serta lingkungan masyarakat pengguna bahan jadi (konsumen). Bahan ini dapat terdiri dari tanaman, tanah, batu-batuan, kebun, sungai dan ladang, pengarajin kayu, rotan (Lasaiba, 2016).

Pemanfaatan lingkungan sebagai media belajar mengarahkan anak pada peristiwa dan 
keadaan yang sebenarnya, keadaan alami sehingga lebih nyata, lebih aktual dan kebenarannya lebih dipertanggung jawabkan, manfaat nyata yang dapat diperoleh dengan penggunaan lingkungan diantaranya adalah : menjadikan berbagai hal yang dapat dipelajari oleh anak-anak, memungkinkan terjadinya proses belajar yang lebih bermakna, memungkinkan terjadinya proses pembentukan kepribadian anak, kegiatan belajar akan lebih menarik bagi anak dan menumbuhkan aktivitas belajar anak.

Saat ini di PAUD Klani berupaya menjawab tuntutan pendidikan yang ada di masa sekarang, namun suatu proses pembelajaran akan lebih bermakna apa bila guru/pendidik mampu menciptakan suasana belajar yang kondusif. Salah satu upaya yang dapat dilakukan untuk menciptakan suasana belajar yang kondusif adalah dengan menyediakan media pembelajaran yang sesuai dengan meteri dan keadaan peserta didik. Rumusan masalah dalam penelitian ini adalah bagaimana meningkatan kemampuan anak dalam mengenal konsep bilangan melalui penggunaan media pembelajaran berbasis alam.

\section{Pengertian Kemampuan}

Usia dini merupakan masa golden age atau fase keemasan. Fase ini merupakan fase terpenting bagi perkembangan anak. Dimana pada masa ini terjadi kematangan fungsi fisik dan psikis yang siap merespon stimulasi yang diberikan oleh lingkungan (Sujiono \& dkk, 2008). Masa ini juga merupakan masa peletak dasar untuk mengembangkan kemampuan kognitif, motorik, bahasa, sosio emosional, agama dan moral.

Kemampuan menurut Kamus Besar Bahasa Indonesia adalah kesanggupan, kekuatan, kecakapan individu dalam berusaha dengan dirinya sendiri. Adapun pengertian mengenal dalam kamus bahasa Indonesia berarti mengetahui, tahu (akan), kenal (akan) sesuatu hal. Sedangkan konsep adalah bentuk, lambang dari bilangan atau angka. Bilangan berarti suatu konsep tentang bilangan yang terdapat unsurunsur penting seperti : nama, urutan, lambang dan jumlah (Nurlela, 2015).

Dari pengertian-pengertian diatas dapat disimpulkan bahwa kemampuan mengenal konsep bilangan adalah kecakapan/ kesanggupan individu/ seseorang dalam mengetahui bentuk (lambang), nama, urutan, bilangan (angka).
Adapun perkembangan konsep mengenal bilangan pada anak usia dini merupakan kemampuan yang sangat penting dalam proses pembelajaran.

\section{Mengenal Bilangan (Angka)}

Perkembangan konsep mengenal bilangan meliputi hal-hal sebagai berikut :

1. Pengenalan kualitas (jumlah) yaitu anakanak menghitung sejumlah benda yang telah ditentukan dilakukan secara bertahab 1-5, 610 kemudian 11-20.

2. Menghafal urutan nama bilangan yaitu menyebutkan nama bilangan (angka) sesuai urutannya yang benar.

3. Menghitung secara rasional dalam arti anak dikatakan memahami bilangan/ angka bila mampu :

a. Menghitung benda sambil menyebutkan nama bilangannya.

b. Membuat korespondensi satu-satu

c. Menyadari atau mengerti bahwa bilangan terakhir yang disebut mewakili total/jumlah benda dalam satu kelompok (Sujiono \& dkk, 2008).

\section{Definisi Media Pembelajaran}

Pengertian media pembelajaran adalah semua alat (bantu) atau benda yang digunakan untuk kegiatan belajar mengajar,dengan maksud menyampaikan pesan (informasi) pembelajaran dari sumber (guru maupun sumber lain) kepada penerima (dalam hal ini anak didik atau warga belajar) (Latuheru, 1988). Media pembelajaran adalah segala sesuatu yang dapat digunakan untuk menyalurkan pesan dari pengirim ke penerima pesan (Sadiman \& dkk, 2008).

Berdasarkan beberapa pendapat di atas, dapat disimpulkan pengertian media pembelajaran sebagai alat bantu mengajar untuk menyampaikan materi agar pesan lebih mudah diterima dan menjadikan siswa lebih termotivasi dan aktif. Pengelompokan atas media dan sumber belajar dapat juga ditinjau dari jenisnya yaitu dibedakan menjadi media visual, media audio, media audio-visual. Berikut adalah pengertian ketiga media pembelajaran tersebut : 
a. Media Visual

Media yang hanya dapat dilihat dengan menggunakan indera penglihatan yang terdiri atas media yang dapat diproyeksikan dan media yang tidak dapat diproyeksikan yang biasanya berupa gambar diam atau gambar bergerak.

b. Media Audio

Media yang mengandung pesan dalam bentuk auditif yang dapat merangsang pikiran, perasaan, perhatian, dan kemauan para peserta didik untuk mempelajari bahan ajar.

c. Media audio-visual

Media yang merupakan kombinasi audio dan visual. Contoh program video/televisi pendidikan dan program slide suara.

Semua jenis media pembelajaran akan terus meningkatkan peran untuk memungkinkan siswa memperoleh manfaat dari pembelajaran yang berbeda (Sadiman \& dkk, 2008). Manfaat media pembelajaran dalam proses belajar mengajar sebagai berikut :

a. Media pembelajaran dapat memperjelas penyajian pesan dan informasi sehingga dapat memperlancar dan meningkatkan proses dan hasil belajar.

b. Media pembelajaran dapat meningkatkan dan mengarahkan perhatian anak sehingga dapat menimbulkan motivasi belajar, interaksi yang lebih langsung antara siswa dengan lingkungannya, dan memungkinkan siswa untuk belajar sendiri-sendiri sesuai dengan kemampuan dan minatnya.

c. Media pembelajaran dapat mengatasi keterbatasan indera, ruang, dan waktu.

d. Media pembelajaran dapat memberikan kesamaan pengalaman kepada siswa tentang peristiwa-peristiwa di lingkungan mereka, serta memungkinkan terjadinyya interaksi langsung dengan guru, masyarakat, dan lingkungan (Arsyad, 2000).

\section{Definisi Media Pembelajaran Berbasis Alam}

Lingkungan alam merupakan salah satu komponen terpenting dalam pengembangan tujuan, isi dan proses pendidikan pada anak usia dini. Esensi tujuan pendidikan pada anak usia dini diantaranya adalah membantu anak memahami dan menyesuaikan diri secara kreatif dengan lingkungannya. Folosofis pembelajaran yang berbasis lingkungan alam sebenarnya telah digagas pertama kali oleh Ligthart (Lasaiba, 2016)dimana ide dasarnya adalah pendidikan pada anak dilakukan dengan mengajak dalam suasana sesungguhnya melalui belajar pada lingkungan alam sekitar yang nyata. Bentuk pengajaran ini dilakukan sebagai upaya menentang bentuk pengajaran yang cenderung intelektualisme dan verbalistik. Menurut Jan Lightghart, sumber utama bentuk pengajaran ini adalah lingkungan di sekitar anak, melalui bentuk pengajaran ini akan tumbuh keaktifan anak dalam mengamati, menyelediki serta mempelajari lingkungan.

Melalui pembelajaran berbasis alam, anak dapat menemukan, memahami dan menerapkan secara langsung proses belajar pada berbagai aspek dalam kehidupan secara nyata. Dengan demikian, anak dapat memaknai bahwa belajar tentang berbagai hal akan memiliki makna dalam kehidupan kini maupun di masa yang akan datang.

\section{Keuntungan Memanfaatkan Media Pembelajaran Berbasis Alam}

Memanfaatkan lingkungan sebagai media pembelajaran memiliki banyak keuntungan antara lain:

a. menghemat biaya karena memanfaatkan benda-benda yang telah ada di lingkungan

b. praktis dan mudah dilakukan tidak memerlukan peralatan khusus seperti listrik

c. pelajaran lebih aplikatif maksudnya materi belajar yang diperoleh siswa melalui media lingkungan kemungkinan besar akan dapat diaplikasikan langsung karena siswa akan sering menemui benda-benda atau peristiwa serupa dalam kehidupannya sehari-hari

d. media lingkungan memberikan pengalaman langsung kepada siswa dengan media lingkungan siswa dapat berinteraksi secara langsung dengan benda, lokasi atau peristiwa sesungguhnya secara alamiah

e. lebih komunikatif sebab benda dan peristiwa yang ada di lingkungan siswa biasanya mudah dicerna oleh siswa, dibandingkan dengan media yang dikemas atau didesain

\section{METODE}

Penelitian ini merupakan Penelitian Tindakan Kelas (PTK) dengan menerapkan proses pembelajaran berbasis alam pada materi tentang konsep bilangan dan dilaksanakan di PAUD Klani Desa Oinlasi Kecamatan Mollo 
Selatan. Penelitian ini dilakukan selama satu bulan mulai tanggal 15 Juni 2016 sampai dengan 15 Juli 2016. Yang menjadi subjek dalam penelitian ini adalah siswa kelas A PAUD Klani Desa Oinlasi Kecamatan Mollo Selatan tahun ajaran 2015/2016 usia 3-4 tahun berjumlah 20 orang dengan rincian laki-laki 7 orang dan perempuan 13 orang. Teknik yang digunakan untuk pengambilan data dalam penelitian ini adalah teknik observasi dan unjuk kerja kemudian data dianalisis menggunakan teknik analisis deskriptif kualitatif.

\section{Prosedur Penelitian}

Rancangan penelitian tindakan dapat dilihat pada gambar 1 .

\section{Refleksi Awal}

Tahap refleksi dilakukan untuk menemukan masalah dalam proses pembelajaran, sehingga bisa mencari solusi yang tepat. Pada tahapan refleksi awal, peneliti menganalisis masalah yang terjadi di kelas khususnya dalam pembelajaran tentang konsep bilangan. Berdasarkan wawancara yang telah dilakukan oleh peneliti, siswa di kelas kurang memahami tentang konsep bilangan. Sehingga kemampuan siswa pada materi ini juga rendah. Hal ini disebabkan karena metode yang dipakai oleh guru dalam mengajarkan materi ini hanya terbatas pada metode ceramah, tanpa didukung dengan penggunaan media.

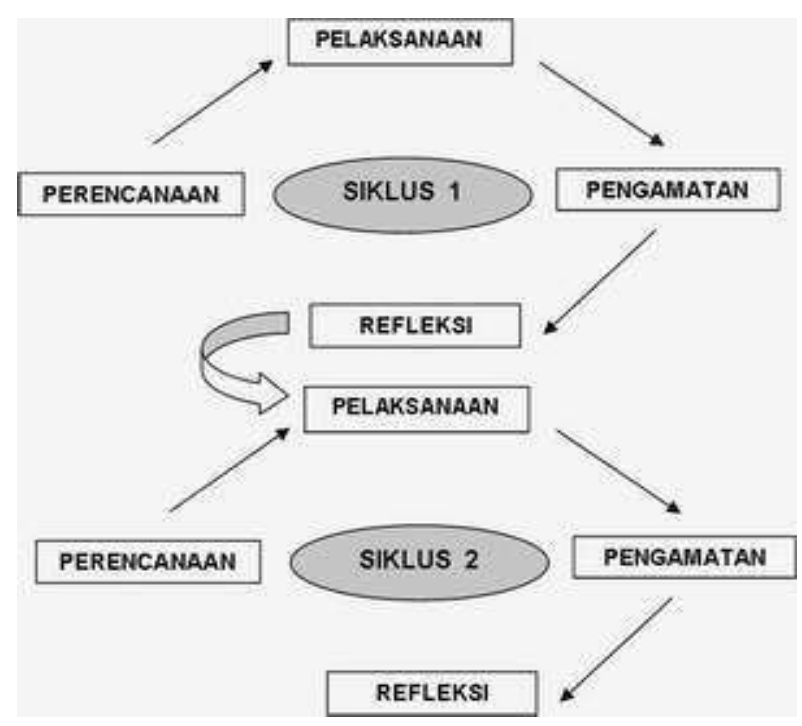

Gambar 1. Riset Aksi Model John Elliot

\section{Siklus I}

\section{a. Perencanaan}

Dalam tahap ini, peneliti menyiapkan RPPH dan media pembelajaran yang akan digunakan dalam proses pembelajaran. Media yang disiapkan berupa kerikil, yang telah diberi nomor 1-10.

\section{b. Pelaksanaan}

Dalam tahap pelaksanaan, peneliti berperan langsung sebagai pengajar (guru) dalam hal ini peneliti akan mengajar tentang konsep bilangan. Langkah-langkah pembelajarannya adalah:

1. Guru membuka kegiatan pembelajaran dengan mengajak anak-anak untuk berdoa bersama

2. Guru mengarahkan anak pada materi yang diajarkan dengan mengajak siswa menyanyikan lagu yang melibatkan bilangan (lagu-lagu yang dinyanyikan dikoordinasikan dengan guru pada sekolah tempat dilakukan penelitian)

3. Guru menyampaikan topik materi yang akan diajarkan yaitu tentang konsep bilangan

4. Guru mengajak anak untuk bermain dengan menggunakan kerikil yang telah disiapkan. Langkah-langkah permainan adalah sebagai berikut :

a. Guru mengajak anak untuk duduk dalam bentuk lingkaran

b. Guru mengajak anak untuk mengambil masing-masing 1 batu yang sudah disiapkan secara acak

c. Guru mengajak anak untuk menyebutkan urutan angka 1-10 (bisa dilakukan dengan menggunakan lagu)

d. Guru mengajak anak untuk bersamasama melihat apa yang tertulis pada batu yang telah dipegang

e. Guru mengenalkan angka 1-10 pada anak sesuai dengan angka pada batu yang dipegang

f. Guru menyuruh anak untuk berdiri sesuai dengan urutan yang tepat menurut angka yang tertera pada batu yang dipegang (bagian ini merupakan bentuk unjuk kerja untuk melihat pemahaman anak tentang materi yang diajarkan)

g. Guru meminta anak untuk membentuk angka 1-10 
menggunakan kerikil yang telah dipersiapkan

5. Guru menutup pelajaran dengan bernyanyi bersama, lalu diakhiri dengan doa.

\section{c. Observasi}

Setelah tahap pelaksanaan maka dilakukan observasi. Observasi dalam penelitian ini dilakukan oleh beberapa observer untuk melihat dan menilai keaktifan siswa selama mengikuti kegiatan pembelajaran.

\section{Refleksi Siklus I}

Dari hasil pembelajaran yang telah dilakukan, peneliti, observer dan guru melakukan evaluasi bersama untuk melihat hasil unjuk kerja dan keefektifan proses pembelajaran. Dengan melihat hasil pembelajaran yang ada, peneliti mempersiapkan siklus 2, jika hasil yang diperoleh tidak sesuai dengan yang diharapkan.

\section{Siklus 2}

Siklus 2 merupakan lanjutan dari siklus 1. Jika pada siklus 1 ketuntasan belajar klasikal belum tercapai maka siklus 2 perlu dilakukan untuk meningkatkan kemampuan siswa. Sedang jika pada siklus 1 ketuntasan belajar klasikal telah tercapai, maka siklus 2 dilakukan guna memberi penguatan atas hasil yang dicapai pada siklus 1 namun tetap dalam upaya meningkatkan kemampuan siswa.

\section{a. Perencanaan}

Pada tahap ini peneliti melakukan revisi pada RPPKH dengan berpedoman pada hasil siklus 1.

\section{b. Pelaksanaan}

Tahap pelaksanaan pada siklus ini, tidak jauh berbeda dengan pada siklus 1 , tapi pada siklus 2 peneliti lebih fokus pada kekurangankekurangan yang dievaluasi pada siklus 1 .

\section{c. Observasi}

Dalam siklus 2 observasi juga dilakukan. Observasi dalam penelitian ini dilakukan oleh beberapa observer untuk melihat dan menilai keaktifan siswa selama mengikuti kegiatan pembelajaran.

\section{d. Refleksi Siklus 2}

Dari hasil pembelajaran yang telah dilakukan, peneliti, observer dan guru melakukan evaluasi bersama untuk melihat hasil unjuk kerja dan keefektifan proses pembelajaran.

\section{Teknik Pengumpulan Data}

a. Sumber Data

1. Data diperoleh dari guru.

2. Jenis data yang di peroleh adalah kualitatif dan data kuantitatif. Data kualitatif di peroleh melalui wawancara dan data kuantitatif diperoleh dari hasil unjuk kerja siswa.

\section{b. Teknik Pengambilan Data}

\section{Observasi}

Observasi merupakan teknik pengumpulan data, dimana peneliti melakukan pengamatan secara langsung ke objek penelitian untuk melihat dari dekat kegiatan yang dilakukan (Riduwan, 2004). Metode observasi sering kali diartikan sebagai pengamatan dan pencatatan secara sistematik terhadap gejala yang tampak pada subyek penelitian. Dalam penelitian ini observasi dilakukan oleh observer untuk mengamati bagaimana keaktifan siswa saat mengikuti kegiatan pembelajaran yang dilakukan menggunakan media berbasis alam.

\section{Unjuk Kerja}

Penilaian ujnuk kerja merupakan penilaian yang dilakukan dengan mengamati kegiatan peserta didik dalam melakukan kegiatan pembelajaran. Penilaian ini cocok digunakan untuk menilai ketercapaian kompetensi yang menuntut peserta didik melakukan tugas tertentu. Penilaian unjuk kerja dapat dilakukan dengan menggunakan daftar cek (Chek-list) atau skala penilaian.

\section{Teknik Analisis Data}

\section{a. Analisis deskriptif kualitatif}

Analisis data deskriptif kualitatif digunakan untuk menganalisa hasil wawancara tentang kondisi sebelum pelaksanaan pembelajaran dan sesudah pembelajaran menggunakan media berbasis alam.

\section{b. Indikator Keberhasilan}

Penelitian ini dikatakan berhasil jika terjadi peningkatan hasil belajar siswa secara klasikal, yaitu siswa yang tuntas $\geq 85 \%$ dengan nilai lebih besar atau sama dengan KKM sekolah, yaitu 70. Untuk menentukan 
ketuntasan klasikal digunakan rumus seperti dibawah ini (Arikunto, 2009):

$$
\text { Nilai }=\frac{\Sigma \text { skor yang diperoleh }}{\Sigma \text { Skor }} \times 100
$$

Sedangkan untuk menentukan ketuntasan klasikal digunakan rumus:

Ketuntasan Klasikal $=\frac{\text { Jumlah siswa yang tuntas }}{\text { Jumlah siswa keseluruha } \mathrm{n}} \times 100 \%$

\section{HASIL DAN PEMBAHASAN}

\section{Hasil Penelitian}

Berdasarkan penelitian yang dilakukan di PAUD Klani Desa Oinlasi Kecamatan Mollo Selatan maka diperoleh hasil sebagai berikut, yang digambarkan dalam tabel 1 di bawah ini.

\section{Tabel 1 Daftar Nilai Hasil Belajar Anak} Pra Siklus

\begin{tabular}{|c|c|c|c|c|}
\hline \multirow[t]{2}{*}{ No } & \multirow{2}{*}{$\begin{array}{l}\text { Nama } \\
\text { Siswa }\end{array}$} & \multirow[t]{2}{*}{$\mathbf{N}$} & \multicolumn{2}{|c|}{ Keterangan } \\
\hline & & & $\mathrm{T}$ & BT \\
\hline 1. & ML & 65 & - & $\sqrt{ }$ \\
\hline 2. & EM & 70 & $\sqrt{ }$ & - \\
\hline 3. & GS & 65 & - & $\sqrt{ }$ \\
\hline 4. & JS & 69 & - & $\sqrt{ }$ \\
\hline 5. & LN & 60 & - & $\sqrt{ }$ \\
\hline 6. & $\mathrm{EF}$ & 70 & $\sqrt{ }$ & - \\
\hline 7. & RT & 67 & - & $\sqrt{ }$ \\
\hline 8. & $\mathrm{AF}$ & 64 & - & $\sqrt{ }$ \\
\hline 9. & AT & 67 & - & $\sqrt{ }$ \\
\hline 10. & PN & 70 & $\sqrt{ }$ & - \\
\hline 11. & IN & 70 & $\sqrt{ }$ & - \\
\hline 12. & NT & 70 & $\sqrt{ }$ & - \\
\hline 13. & NS & 60 & - & $\sqrt{ }$ \\
\hline 14. & GN & 60 & - & $\sqrt{ }$ \\
\hline 15. & WL & 60 & - & $\sqrt{ }$ \\
\hline 16. & YAN & 65 & - & $\sqrt{ }$ \\
\hline 17. & YS & 68 & - & $\sqrt{ }$ \\
\hline 18. & LM & 66 & - & $\sqrt{ }$ \\
\hline 19. & $\mathrm{MN}$ & 68 & - & $\sqrt{ }$ \\
\hline 20. & $\mathrm{RN}$ & 65 & - & $\sqrt{ }$ \\
\hline & Jumlah & & 5 & 15 \\
\hline
\end{tabular}

Sumber data : Hasil penilaian pendidik selama proses pembelajaran

$* N=$ Nilai, $T=$ Tuntas, $B T=$ Belum Tuntas

Tabel 2 Persentase Ketuntasan Belajar Pra Siklus

\begin{tabular}{ccccc}
\hline \multirow{2}{*}{$\begin{array}{c}\text { Jumlah } \\
\text { Siswa }\end{array}$} & \multicolumn{2}{c}{ Tuntas } & \multicolumn{3}{c}{ Belum Tuntas } \\
\cline { 2 - 5 } 2 & $\sum$ & $\%$ & $\sum$ & $\%$ \\
\hline 20 & 5 & 25 & 15 & 75
\end{tabular}

Sumber data : Olahan Peneliti
Tabel 3. Hasil Penilaian Unjuk Kerja Siklus I

\begin{tabular}{|c|c|c|c|c|c|c|c|c|c|c|c|c|c|}
\hline \multirow[t]{2}{*}{ No } & \multicolumn{10}{|c|}{ Nomor Soal } & \multirow[t]{2}{*}{$\mathbf{N}$} & \multicolumn{2}{|c|}{ Ket } \\
\hline & 1 & 2 & 3 & 4 & 5 & 6 & 7 & 8 & 9 & 10 & & $\mathrm{~T}$ & BT \\
\hline $\mathbf{1}$ & $\sqrt{ }$ & $\sqrt{ }$ & $\sqrt{ }$ & - & - & $\sqrt{ }$ & $\sqrt{ }$ & - & - & $\sqrt{ }$ & 60 & - & $\sqrt{ }$ \\
\hline 2 & $\sqrt{ }$ & $\sqrt{ }$ & - & $\sqrt{ }$ & $\sqrt{ }$ & $\sqrt{ }$ & $\sqrt{ }$ & $\sqrt{ }$ & $\sqrt{ }$ & $\sqrt{ }$ & 90 & $\sqrt{ }$ & - \\
\hline 3 & $\sqrt{ }$ & $\sqrt{ }$ & T & $\sqrt{ }$ & $\sqrt{ }$ & $\sqrt{ }$ & $\sqrt{ }$ & - & $\sqrt{ }$ & $\sqrt{ }$ & 80 & $\sqrt{ }$ & - \\
\hline 4 & $\sqrt{ }$ & $\sqrt{ }$ & - & $\sqrt{ }$ & - & - & $\sqrt{ }$ & - & $\sqrt{ }$ & $\sqrt{ }$ & 60 & - & $\sqrt{ }$ \\
\hline 5 & $\sqrt{ }$ & - & - & $\sqrt{ }$ & $\sqrt{ }$ & $\sqrt{ }$ & $\sqrt{ }$ & - & - & $\sqrt{ }$ & 60 & - & $\sqrt{ }$ \\
\hline 6 & $\sqrt{ }$ & $\sqrt{ }$ & - & $\sqrt{ }$ & $\sqrt{ }$ & $\sqrt{ }$ & $\sqrt{ }$ & $\sqrt{ }$ & $\sqrt{ }$ & $\sqrt{ }$ & 90 & $\sqrt{ }$ & - \\
\hline 7 & $\sqrt{ }$ & $\sqrt{ }$ & $\sqrt{ }$ & $\sqrt{ }$ & $\sqrt{ }$ & $\sqrt{ }$ & $\sqrt{ }$ & - & $\sqrt{ }$ & $\sqrt{ }$ & 90 & $\sqrt{ }$ & - \\
\hline 8 & $\sqrt{ }$ & - & - & $\sqrt{ }$ & $\sqrt{ }$ & $\sqrt{ }$ & $\sqrt{ }$ & - & $\sqrt{ }$ & $\sqrt{ }$ & 70 & $\sqrt{ }$ & - \\
\hline 9 & $\sqrt{ }$ & - & - & $\sqrt{ }$ & - & $\sqrt{ }$ & $\sqrt{ }$ & - & $\sqrt{ }$ & $\sqrt{ }$ & 60 & - & $\sqrt{ }$ \\
\hline 10 & $\sqrt{ }$ & $\sqrt{ }$ & $\sqrt{ }$ & $\sqrt{ }$ & $\sqrt{ }$ & $\sqrt{ }$ & $\sqrt{ }$ & - & $\sqrt{ }$ & $\sqrt{ }$ & 90 & $\sqrt{ }$ & - \\
\hline 11 & $\sqrt{ }$ & - & $\sqrt{ }$ & $\sqrt{ }$ & $\sqrt{ }$ & $\sqrt{ }$ & $\sqrt{ }$ & $\sqrt{ }$ & $\sqrt{ }$ & $\sqrt{ }$ & 90 & $\sqrt{ }$ & - \\
\hline 12 & $\sqrt{ }$ & $\sqrt{ }$ & - & $\sqrt{ }$ & $\sqrt{ }$ & $\sqrt{ }$ & $\sqrt{ }$ & $\sqrt{ }$ & $\sqrt{ }$ & $\sqrt{ }$ & 90 & $\sqrt{ }$ & - \\
\hline 13 & $\sqrt{ }$ & - & - & $\sqrt{ }$ & - & $\sqrt{ }$ & $\sqrt{ }$ & - & $\sqrt{ }$ & $\sqrt{ }$ & 60 & - & $\sqrt{ }$ \\
\hline 14 & $\sqrt{ }$ & - & - & $\sqrt{ }$ & - & $\sqrt{ }$ & $\sqrt{ }$ & $\sqrt{ }$ & $\sqrt{ }$ & $\sqrt{ }$ & 70 & $\sqrt{ }$ & - \\
\hline 15 & $\sqrt{ }$ & - & $\sqrt{ }$ & $\sqrt{ }$ & $\sqrt{ }$ & $\sqrt{ }$ & $\sqrt{ }$ & $\sqrt{ }$ & $\sqrt{ }$ & $\sqrt{ }$ & 90 & $\sqrt{ }$ & - \\
\hline 16 & $\sqrt{ }$ & - & - & $\sqrt{ }$ & - & $\sqrt{ }$ & $\sqrt{ }$ & - & $\sqrt{ }$ & $\sqrt{ }$ & 60 & - & $\sqrt{ }$ \\
\hline 17 & $\sqrt{ }$ & - & - & $\sqrt{ }$ & - & $\sqrt{ }$ & $\sqrt{ }$ & - & $\sqrt{ }$ & $\sqrt{ }$ & 60 & - & $\sqrt{ }$ \\
\hline 18 & $\sqrt{ }$ & - & - & $\sqrt{ }$ & $\sqrt{ }$ & $\sqrt{ }$ & $\sqrt{ }$ & $\sqrt{ }$ & $\sqrt{ }$ & $\sqrt{ }$ & 80 & $\sqrt{ }$ & - \\
\hline 19 & $\sqrt{ }$ & - & - & $\sqrt{ }$ & - & $\sqrt{ }$ & $\sqrt{ }$ & - & $\sqrt{ }$ & $\sqrt{ }$ & 60 & - & $\sqrt{ }$ \\
\hline 20 & $\sqrt{ }$ & - & - & $\sqrt{ }$ & - & $\sqrt{ }$ & $\sqrt{ }$ & - & $\sqrt{ }$ & $\sqrt{ }$ & 60 & - & $\sqrt{ }$ \\
\hline \multicolumn{11}{|c|}{ Jumlah } & & 11 & 9 \\
\hline \multicolumn{11}{|c|}{ Rata-rata } & 67,5 & & \\
\hline \multicolumn{11}{|c|}{ Persentase } & & 55 & 45 \\
\hline
\end{tabular}

Tabel 4. Persentase Ketuntasan Belajar Siklus I

\begin{tabular}{cccccc} 
Jumlah & \multicolumn{2}{c}{ Tuntas } & \multicolumn{3}{c}{ Belum Tuntas } \\
\cline { 2 - 5 } Siswa & $\sum$ & $\%$ & $\sum$ & $\%$ & \\
\hline 20 & 11 & 55 & 9 & 45
\end{tabular}

Hasil pra siklus yang ditunjukkan pada tabel 1 dan 2 tersebut diperoleh dari pendidik di PAUD Klani. Menindaklanjuti hasil pra siklus tesebut maka peneliti melakukan penelitian tindakan kelas yang dilakukan dalam dua siklus. Hasil yang diperoleh dapat dilihat pada tabel 3 dan 4 di atas.

Berdasarkan hasil penilaian siklus I maka maka dilihat bahwa anak (siswa) yang dapat mencapai kriteria ketuntasan minimum (KKM) berjumlah 11 orang sedangkana anak (siswa) yang belum dapat mencapai kriteria ketuntasan minimum (KKM) berjumlah 9 orang, sehingga penelitian ini berlanjut ke siklus II. Hasil penelitian siklus II dapat dilihat pada tabel 5. Berdasarkan hasil penilaian unjuk kerja anak pada siklus II, maka persentase ketuntasan belajar dapat dilihat pada tabel 6 di bawah ini. 
Tabel 5. Hasil Penilaian Unjuk Kerja Siklus II

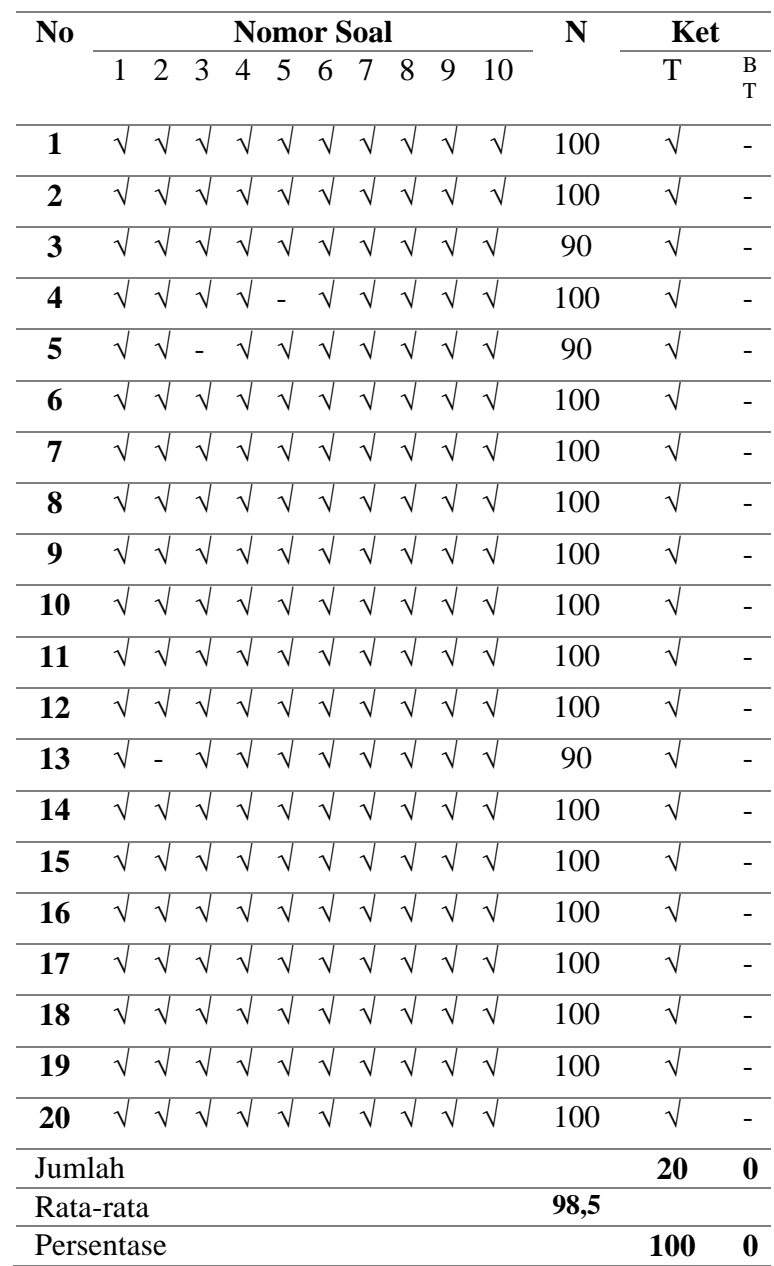

Sumber data: hasil unjuk kerja anak (siswa)

Tabel 6. Persentase Ketuntasan Belajar Siklus I

\begin{tabular}{ccccc}
\hline Jumlah & \multicolumn{2}{c}{ Tuntas } & \multicolumn{2}{c}{ Belum Tuntas } \\
\cline { 2 - 5 } Siswa & $\sum$ & $\%$ & $\sum$ & $\%$ \\
\hline 20 & 20 & 100 & 0 & 0 \\
\hline
\end{tabular}

\section{Pembahasan}

Penelitian tindakan kelas melalui penggunaan media pembelajaran berbasis alam (kerikil) dilaksanakan selama empat minggu mulai tanggal 15 Juni 2016 sampai dengan 15 Juli 2016. Penelitian ini dilaksanakan dalam dua siklus dengan enam kali pertemuan.

Sebelum memulai penelitian, peneliti melakukan observasi hasil belajar siswa tentang pengenalan konsep bilangan berdasarkan nilai atau hasil belajar yang diperoleh dari pendidik melalui proses pembelajaran dan penilaian di kelas A
PAUD Klani Desa Oinlasi Kecamatan Mollo Selatan. Hasil penilaian tersebut dapat dilihat pada tabel 1. Pengambilan nilai atau hasil belajar siswa dilakukan untuk mengetahui sejauh mana tingkat pemahaman dan keberhasilan siswa dalam memahami materi tentang pengenalan konsep bilangan. Persentase ketuntasan belajar anak dalam mengenal konsep bilangan dapat dilihat pada tabel 2 . Berdasarkan hasil pengolahan data pada tabel 2 dapat kita lihat bahwa pembelajaran tentang pengenalan konsep bilangan pada kelas A belum mencapai ketuntasan baik secara individu maupun klasikal. Dari data di atas dapat dilihat bahwa dari 20 orang siswa hanya terdapat 5 orang siswa yang dapat mencapai kriteria ketuntasan minimum (KKM) dalam proses pembelajaran tentang pengenalan konsep bilangan, dan secara klasikal ketuntasan belajar hanya mencapai $25 \%$.

Setelah memperoleh data tentang hasil belajar siswa peneliti mulai menerapkan metode pembelajaran menggunakan media berbasis alam yaitu batu kerikil menggunakan siklus I berdasarkan langkah-langkah yang telah direncanakan pada siklus I selama dua kali pertemuan dan kemudian melakukan unjuk kerja pada pertemuan ke dua untuk mengukur perkembangan keberhasilan pembelajaran melalui metode dan media yang telah diterapkan.

\section{Hasil Siklus I}

Siklus I dilaksanakan dalam dua kali pertemuan kemudian pada pertemuan ketiga dilakukan unjuk kerja untuk menilai ketuntasan belajar siswa. Siklus I ini terdiri dari empat tahap yaitu tahap perencanaan, tahap pelaksanaan, tahap pengamatan, dan tahap refleksi. Keempat tahap tersebut dapat dijelaskan seperti dibawah ini:

\section{Tahap Perencanaan}

Pada tahap perencanaan ini peneliti mempersiapkan semua kelengkapan yang akan digunakan dalam penelitian. Kelengkapan tersebut meliputi:

a. Menyiapkan rencana pelaksanaan pembelajaran harian (RPPH), lembar observasi, daftar hadir siswa dan daftar nilai 
b. Menyiapkan media pembelajaran dari bahan alam berupa kerikil yang telah diberi nomor atau angka 1-10

c. Menyiapkan alat dokumentasi

\section{Tahap Pelaksanaan}

Tahap ini merupakan tahap pelaksanaan pembelajaran di dalam kelas. Pada awal pembelajaran guru menyampaikan tujuan pembelajaran, yaitu agar siswa dapat pembelajaran tentang pengenalan konsep bilangan menggunakan media pembelajaran berbasis alam (kerikil). Selanjutnya guru mulai melakukan proses belajar mengajar menggunakan media yang telah dipersiapkan berdasarkan langkahlangkah yang telah diuraikan pada prosedur penelitian.

Langkah terakhir adalah guru meminta siswa melakukan unjuk kerja, setelah melakukan unjuk kerja guru mengajak siswa untuk bermain permainan, kemudian menutup kegiatan pembelajaran dengan bernyanyi dan berdoa bersama.

\section{Tahap Pengamatan}

Tahap ini dilakukan untuk Untuk mengetahui peningkatan kemampuan belajar siswa tentang pengenalan konsep bilangan maka dilakukan unjuk kerja bagi siswa. Hasil unjuk kerja ini kemudian dibandingkan dengan hasil belajar yang diperoleh dari guru sebelum penerapan pembelajaran menggunakan media berbasis alam (kerikil) agar dapat mengukur presentase ketuntasan siswa baik secara individu maupun klasikal. Hasil dari unjuk kerja siklus I tersebut dapat dilihat pada tabel 3 sedangkan persentase ketuntasan hasil belajar siswa dapat dilihat pada tabel 4 , berdasarkan data dalam tabel 4 dapat dilihat bahwa siswa yang tuntas dalam penilaian unjuk kerja siklus I berjumlah 11 orang dan mencapai persentase 55\%. Persentase ini mengalami peningkatan sebesar $30 \%$ dari nilai pra siklus. Nilai tertinggi dari hasil unjuk kerja ini adalah 90 dan nilai terendah adalah 60 dari 20 orang siswa, sedangkan siswa yang belum tuntas berjumlah 9 orang dan mencapai persentase $45 \%$.

\section{Tahap Refleksi}

Pada tahap ini peneliti bersama observer dan guru memberikan tanggapan atau masukan bagi peneliti terkait dengan jalannya proses penelitian serta respon siswa dalam mengikuti kegiatan pembelajaran yang telah diterapkan. Dari hasil refleksi yang dilakukan oleh peneliti, observer dan guru maka diketahui bahwa kebanyakan siswa memberi respon positif dan dapat berpartisipasi dalam kegiatan pembelajaran, namun meraka lebih bersikap aktif ketika kegiatan pembelajaran mulai menggunakan media berbasis alam yang dipersiapkan berupa batu kerikil yang telah diberi nomor (angka) 1-10.

Selain itu, dilihat dari hasil penilaian unjuk kerja kebanyakan siswa belum mampu menunjukan dan membentuk angka 2,3,5 dan 8 dari media yang telah dipersiapkan yaitu batu kerikil.

\section{Hasil Siklus II}

Siklus II merupakan kelanjutan dari siklus I. Jika pada siklus I peningkatan kemampuan anak secara klasikal dan individu belum tercapai, maka siklus II perlu dilakukan untuk meningkatkan kemampuan anak dalam belajar. Sedang jika pada siklus I ketuntasan belajar klasikal dan individu telah tercapai, maka siklus II dilakukan guna memberi penguatan atas hasil yang dicapai pada siklus I namun tetap dalam upaya meningkatkan kemampuan dan hasil belajar siswa. Siklus II ini juga dilaksanakan dalam dua kali pertemuan kemudian pada pertemuan ketiga dilaksanakan unjuk kerja. Pada siklus ini juga dilakukan dalam empat tahap yaitu tahap perencanaan, tahap pelaksanaan, tahap pengamatan dan tahap refleksi. Keempat tahap ini dapat dijelaskan sebagai berikut :

\section{Tahap Perencanaan}

Pada tahap perencanaan ini guru mempersiapkan semua kelengkapan yang akan digunakan dalam penelitian. Kelengkapan tersebut meliputi:

a. Menyiapkan rencana pelaksanaan pembelajaran harian (RPPH), lembar observasi, daftar hadir siswa dan daftar nilai

b. Menyiapkan media pembelajaran dari bahan alam berupa kerikil yang telah diberi nomor atau angka 1-10

c. Menyiapkan alat dokumentasi

\section{Tahap Pelaksanaan}

Tahap ini merupakan tahap pelaksanaan pembelajaran di dalam kelas. Pada awal pembelajaran guru 
menyampaikan tujuan pembelajaran, yaitu agar siswa dapat pembelajaran tentang pengenalan konsep bilangan menggunakan media pembelajaran berbasis alam (kerikil). Selanjutnya guru mulai melakukan proses belajar mengajar menggunakan media yang telah dipersiapkan dengan menitikberatkan fokus pembelajaran pada siswa yang belum tuntas yaitu lebih memperhatikan dan mengontrol sehingga siswa yang belum tuntas menjadi prioritas utama dalam proses belajar mengajar dan memberi penjelasan secara berulang-ulang dengan penekanan pada angka 2,3,5 dan 8 yang merupakan angka-angka yang sulit diingat oleh siswa berdasarkan hasil refleksi siklus I.

Langkah terakhir adalah guru meminta siswa melakukan unjuk kerja, untuk melihat keberhasilan siklus ini, setelah melakukan unjuk kerja guru mengajak siswa untuk bermain permainan kemudian menutup kegiatan pembelajaran dengan bernyanyi dan berdoa bersama.

\section{Tahap Pengamatan}

Tahap ini dilakukan untuk mengetahui peningkatan kemampuan belajar siswa tentang pengenalan konsep bilangan maka dilakukan unjuk kerja siklus II bagi siswa. Hasil unjuk kerja siklus II ini kemudian dibandingkan dengan hasil penilaian unjuk kerja siklus I pembelajaran menggunakan media berbasis alam (kerikil) agar dapat mengukur presentase ketuntasan siswa baik secara individu maupun klasikal hasil unjuk kerja siswa dapat dilihat pada tabel 5 sedangkan persentase ketuntasan belajar anak pada siklus ini dapat dilihat pada tabel 6. Berdasarkan data dalam tabel maka dapat dilihat bahwa siswa yang tuntas dalam penilaian unjuk kerja siklus II berjumlah 20 orang dan mencapai persentase $100 \%$. Persentase ini mengalami peningkatan sebesar $45 \%$ dari pelaksanaan silkus I. Nilai tertinggi dari unjuk kerja ini adalah 100 dan nilai terendah adalah 90 dari 20 orang siswa.

Dari hasil penelitian diatas diketahui bahwa penerapan media pembelajaran berbasis alam (kerikil) dapat meningkatkan kemampuan siswa dalam memahami materi tentang pengenalan konsep bilangan di PAUD Klani Desa Oinlasi Kecamatan Mollo Selatan.

Presentase ketuntasan belajar siswa dilihat dari hasil penilaian unjuk kerja yang diberikan oleh peneliti pasca siklus II. Presentase menunjukan adanya peningkatan dari kegiatan pasca siklus II . Nilai ini diperoleh dengan melihat selisih rata-rata presentase siklus I dengan ratarata presentase siklus II. Jadi, secara keseluruhan kemampuan belajar siswa mengalami peningkatan sebesar $45 \%$.

\section{Tahap Refleksi}

Pada tahap ini peneliti bersama observer dan guru memberikan tanggapan atau masukan bagi peneliti terkait dengan jalannya proses penelitian serta respon siswa dalam mengikuti kegiatan pembelajaran yang telah diterapkan. Dari hasil refleksi yang dilakukan oleh peneliti, observer dan guru maka diketahui bahwa pembelajaran menggunakan media pembelajaran berbasis alam telah mencapai hasil maksimum. Hal ini ditandai dengan keberhasilan dan peningkatan kemampuan siswa dalam memamhami materi dimaksud dan telah mampu mencapai kriteria ketuntasan minimum (KKM) baik secara klasikal maupun individu.

\section{SIMPULAN}

Berdasarkan hasil dan pembehasan hasil penelitian maka dapat disimpulkan bahwa hasil pembelajaran tentang pengenalan konsep bilangan di kelas A PAUD Klani pra siklus belum mencapai kriteria ketuntasan minimum (KKM) baik secara individu maupun secara klasikal hal ini dilihat dari persentase ketuntasan belajar siswa yang hanya mencapai $25 \%$. Sedangkan pada siklus I persentase ketuntasan belajar siswa tentang pengenalan konsep bilangan mengalami kenaikan dari $25 \%$ menjadi $55 \%$ namun belum semua siswa mengalami peningkatan kemampuan dalam memahami materi tentang pengenalan konsep bilangan sehingga penelitian ini berlanjut ke siklus II, dan pada siklus II kemampuan anak dalam memahami materi tentang pengenalan konsep bilangan mengalami peningkatan secara menyeluruh baik individu maupun klasikal 
Jurnal PG-PAUD Trunojoyo : Jurnal Pendidikan dan Pembelajaran Anak Usia Dini, Volume

sehingga persentase ketuntasan belajar siswapun mengalami peningkatan dari 55\% menjadi $100 \%$.

\section{Saran}

Berdasarkan kesimpulan di atas maka peneliti memberikan beberapa saran yang diharapkan dapat meningkatkan kemampuan belajar dan mutu atau kualitas pendidikan :

a. Bagi guru dapat melihat dan menggunakan potensi alam yang ada disekitar sebagai sumber belajar bagi anak usia dini sehingga anak dapat belajar secara aktif.

b. Bagi lembaga dapat memfasilitasi kegiatan pembelajaran di PAUD dengan mendesain benda-benda yang ada disekitar lingkungan alam sebagai sumber belajar.

\section{DAFTAR PUSTAKA}

Ambarsari, E., Syukri, M., \& Miranda, D. (2014). Peningkatan Kemandirian Anak Melalui Metode Pembiasaan Usia 4- 5 Tahun di Taman Kanak Kanak Mujahidin I. Jurnal Pendidikan Dan Pembelajaran, 3(9), 1-13.

Arikunto, Suharsimi. (2009). Dasar-Dasar Evaluasi Pendidikan. Jakarta: PT Bumi Aksara

Arsyad, A. (2000). Media Pengajaran. Jakarta: PT Raja Grafindo Persada.

Lasaiba, D. (2016). Pola Pengembangan Model Pembelajaran Pendidikan Anak Usia Dini di Lingkungan IAIN Ambon. Jurnal Fikratuna, Volume 8 Nomor 2.

Latuheru, J. D. (1988). Media Pembelajaran dalam Proses Belajar Masa Kini. Jakarta: Depdikbud.

Nazariah. (2016). Penggunaan Media Kartu

ABACA Flashcards dalam Pembelajaran

Pengenalan Huruf Abjad untuk Anak Usia

Dini. Bunayya: Jurnal Pendidikan Anak, l(2), 50-66.

Nurlela, S. (2015). Meningkatkan Keterampilan Sosial Anak Usia Dini Melalui Permainan Tradisional Jamuran di TK Al-Manshuriyyah. Retrieved from
Universitas Pendidikan Indonesia: http://www.repository.upi.edu

Riduwan. (2004). Metode Riset. Jakarta: Rineka Cipta.

Sadiman, A., \& dkk. (2008). Media Pendidikan: Pengertian, Pengembangan, dan Pemanfaatannya. Jakarta: PT Raja Grafindo Persada.

Sujiono, B., \& dkk. (2008). Metode Pengembangan Fisik. Jakarta: Universitas Terbuka.

Tursiyah, R., M., \& Halida. (2014). Peningkatan Perkembangan Motorik Kasar Anak dalam Pembelajaran Senam Irama Menggunakan Alat Permainan Simpai. Jurnal Pendidikan Dan Pembelajaran, 3(10), 1-10.

Zein, M. (2016). Peran Guru dalam Pengembangan Pembelajaran. Jurnal Pendidikan Agama Islam IAIN Ternate, V(2), Juli - Desember. 